\title{
Contextual Effect of Village on the Incidence of Tuberculosis in Children in Surakarta, Central Java: A Multilevel Analysis Evidence
}

\author{
Dyah Ayu Saputri'), Yulia Lanti Retno Dewi²), Bhisma Murti') \\ 1)Masters Program in Public Health, Universitas Sebelas Maret \\ 2)Faculty of Medicine, Universitas Sebelas Maret
}

\begin{abstract}
Background: Indonesia is in the second place with the highest burden of tuberculosis (TB) in the world. Childhood is a period of rapid growth that requires efforts to maintain children's health. At the time the child still has a low immune system making it vulnerable to a disease including TB. The problem of TB in children requires better attention in child TB control programs. This study aimed to analyze the contextual influence of villages on the incidence of TB in children.

Subjects and Method: This was a case-control study conducted in 25 villages in Surakarta, Central Java, from August to September 2019. A sample of 200 children aged o to 18 years was selected by fixed disease sampling. The dependent variable was the incidence of TB in children. The independent variables were birth weight, BCG immunization, exclusive breastfeeding, nutritional status, parental income, home sanitation, exposure to cigarette smoke, family history of TB, and contextual effect of village. Data on TB were obtained from medical record in Surakarta community health center. The other data was collected by questionnaire. The data was analyzed by multilevel multiple logistic regression with Stata 13.

Results: The risk of TB in children increased poor house sanitation $(\mathrm{OR}=6.70 ; 95 \% \mathrm{CI}=1.14$ to 39.27; $\mathrm{p}=0.035)$, high exposure to cigarette smoke $(\mathrm{OR}=6.71 ; 95 \% \mathrm{CI}=1.09$ to $41.25 ; \mathrm{p}=0.040)$, and family history of $\mathrm{TB}(\mathrm{OR}=6.01 ; 95 \% \mathrm{CI}=1.36$ to $26.39 ; \mathrm{p}=0.018)$. The risk of $\mathrm{TB}$ in children decreased with normal birth weight $(\geq 2500 \mathrm{~g})(\mathrm{OR}=0.12 ; 95 \% \mathrm{CI}=0.02$ to $0.60 ; \mathrm{p}=0.009)$, BCG immunization ( $\mathrm{OR}=0.17 ; 95 \% \mathrm{CI}=0.04$ to $0.64 ; \mathrm{p}=0.009)$, exclusive breastfeeding $(\mathrm{OR}=0.08$; $95 \% \mathrm{CI}=0.01$ to $0.57 ; \mathrm{p}=0.011)$, good nutritional status $(\mathrm{OR}=0.11 ; 95 \% \mathrm{CI}=0.02$ to $0.66 ; \mathrm{p}=$ $0.016)$, and parental income $\geq \mathrm{Rp} 1,802,700(\mathrm{OR}=0.07 ; 95 \% \mathrm{CI}=0.01$ to $0.37 ; \mathrm{p}=0.002)$. Village had strong contextual effect on the risk of $\mathrm{TB}$ in children with intra-class correlation $(\mathrm{ICC})=$ $29.24 \%$.

Conclusion: The risk of TB in children increases poor house sanitation, high exposure to cigarette smoke, and family history of TB. The risk of TB in children decreases with birth weight $\geq 2500 \mathrm{~g}$, BCG immunization, exclusive breastfeeding, good nutritional status, and high parental income. Village has strong contextual effect on the risk of TB in children.
\end{abstract}

Keywords: Tuberculosis, risk factors, children aged o-18 years, multilevel analysis.

\section{Correspondence:}

Dyah Ayu Saputri. Masters Program in Public Health, Universitas Sebelas Maret, Jl. Ir. Sutami 36 A, Surakarta, Central Java 57126. Email: ayusaputridyah7@gmail.com. Mobile: o81353236388.

\section{BACKGROUND}

Childhood is a period of rapid growth and development, so there is a need for efforts to maintain children's health aimed at forming healthy, intelligent and quality future generations and to reduce child mortality. Efforts to maintain children's health from the time the fetus was still in the womb until the age of 18 years. Children still have a low immune system so they are vulnerable to a disease including tuberculosis (TB) (Ministry of Heal, 2019).

TB is still the tenth highest cause of death in the world, until now TB is still a 
Journal of Epidemiology and Public Health (2019), 4(4): 361-372

https://doi.org/10.26911/jepublichealth.2019.04.04.11

top priority in the world and is one of the goals in the SDGs (Sustainability Defense Goals) (World Health Organization, 2016.) Five countries with the highest TB incidence are India, Indonesia, China, the Philippines and Pakistan. Indonesia ranks second with the highest TB burden in the world. Trends in incident TB cases that have not been reached and detected, even if detected and treated but have not been reported (Ministry of Health, 2019).

The 2013 Basic Health Research Data (Riskesdas) states that pulmonary TB has been diagnosed in the $<1$ year age group by $2 \%$, the 1 to 4 year age group by $4 \%$, the $5^{-}$ 18 year age group by $3 \%$, whereas in the age group of people other adults also showed a similar prevalence of $3 \%$. The results of the 2013 Riskesdas study also showed that there was a recent health problem related to the incidence of pulmonary TB that had attacked the age group of children (Ministry of health, 2015).

The problem of $\mathrm{TB}$ in children requires better attention in TB control programs. The main challenges in pediatric TB control programs are a tendency to overdiagnosis or under-diagnosis of pediatric TB cases, inadequate case management, case tracking has not been routinely carried out and under-reporting of pediatric TB patients. Risk factors for childhood TB events in Indonesia are related to child factors (nutritional status, birth weight, history of exclusive breastfeeding and immunization status), parental factors (education, employment, income and knowledge), environmental factors and contact with adult $\mathrm{TB}$ sufferers (Aziz, 2018).

\section{SUBJECTS AND METHOD}

\section{Study Design}

This was an observational analytic method with a case-control study approach. The study was conducted in 25 villages spread in each working area of UPT Puskesmas Surakarta. It was conducted August-September 2019.

\section{Population and Sample}

The population in this study were children aged 0-18 years amounting to 200 subjects. Sampling in this study uses fixed disease sampling with a ratio of 1:3 of children who live in 25 villages spread in each working area of UPT Puskesmas in Surakarta City.

\section{Variables of Study}

The dependent variable was the incidence of TB in children. The independent variables were birth weight, BCG immunization, history of exclusive breastfeeding, nutritional status, parental income, home sanitation, exposure to cigarette smoke, family history of TB, and contextual village.

\section{Operational Definition of Variables} Incidence of $T B$ children aged $0-18$ years were children aged $0-18$ years who are diagnosed with TB by a doctor or health worker at the moment or based on the notes in the medical record book (Medical Record). The measuring instrument used was the medical record. The data scale was categorical with grouping data $1=$ tuberculosis, $\mathrm{o}=$ no tuberculosis.

Birth weight was the baby's weight at birth regardless of gestational age and is expressed in grams. The measuring tool was a baby scale. The scale of the data was continuous, but for analytical purposes the data were converted into a dichotomy by grouping data $0=$ low $(<2,500 \mathrm{~g}), 1=$ normal $(\geq 2,500 \mathrm{~g})$.

BCG immunization was a vaccine given to protect themselves against TB on a schedule that is appropriate to their age, based on the immunization schedule recommended by the Indonesian Ministry of Health. The measuring instrument used was a questionnaire. The data scale was categorical with data grouping $\mathrm{O}=$ no $\mathrm{BCG}$ immunization, 1 = BCG immunization. 
History of exclusive breastfeeding was only breastfeeding from birth until the age of 6 months without providing additional food and or drinks except drugs or vaccines with medical indications. The measuring instrumentwas a questionnaire. The scale of the data was categorical with grouping of data $\mathrm{O}=$ no exclusive breastfeeding, $1=\mathrm{ex}-$ clusive breastfeeding.

Nutritional Status was a state of nutritional status of children which is calculated based on anthropometric measurements (BMI/age) using the WHO anthropometric program. The measuring instrument was a stampede scale. The scale of the data was continuous, but for analytical purposes, the data was converted into a dichotomy by grouping data $0=$ malnutrition, $1=\operatorname{good}$ nutrition.

Parental education was the highest level of formal schooling achieved by structured and tiered parents, assessed based on the last diploma obtained. basic or low education (elementary, junior high, equivalent) and further or higher education (high school, academy, university). Based on the $\mathrm{Na}$ tional Education System Law No. 20 of 2003. Questionnaires was the measurement tools (checklist). The way to measure it was with interview. The scale of the data was categorical with data grouping $\mathrm{O}=$ Low (elementary, junior high, equivalent), 1 = high (high school, academy, university).

Parent income was the average amount of income each month for the past 6 months that the family has received in the form of honorarium, rent including subsidies or benefits and expressed in rupiah. The measuring instrument was a questionnaire. The scale of the data was continuous, then for the data analysis, data were converted into categorical data by grouping data as $\mathrm{O}=$ low ( $<$ minimum wage Rp. 1,802,700), $1=$ high ( $\geq$ minimum wage (Rp. 1,802,700).
House sanitation was a sanitation condition of a house inside a house that consists of air humidity, house ventilation, temperature of the house, natural lighting and density of residents. The measuring tool was an observation checklist. The scale of the data was continuous before then changed into categorical for the purpose of analysis by grouping the data as $\mathrm{O}=$ not meeting healthy requirements (score <20), $1=$ meeting healthy requirements (score $-\geq 20$ ).

Exposure to cigarette smoke was exposure to cigarette smoke at home that comes from family members who smoke who live in the same household with children. The measuring instrument was a questionnaire. The data scale was categorical with the grouping of data as $\mathrm{O}=$ there are families who smoke, 1 = no families who smoke.

Family TB history was a family that has been diagnosed with TB by a doctor or health worker at this time or who is based on a record in a medical record book. The measuring instrument was a medical record. The data scale was categorical with grouping data $\mathrm{O}=$ there is a family history of $\mathrm{TB}$, $1=$ there is no family history of TB.

The economic status of the village was the economic status of the village is the economic capacity of a village which is reflected in the percentage of poor people in the village. The measurement tool was a questionnaire containing data on the economic status of the village determined by the Regional Planning and Development Agency (BAPPEDA) based on data from the Central Statistics Agency (BPS) which was the result of data analysis of the National SocioEconomic Survey (Susenas).

\section{Data Analysis}

Univariate analysis was carried out to describe the general picture of each variable studied. Bivariate analysis was performed to describe the effect of one independent variable on a dependent variable. Multiva- 
Journal of Epidemiology and Public Health (2019), 4(4): 361-372

https://doi.org/10.26911/jepublichealth.2019.04.04.11

riate analysis was carried out to describe the effect of more than one independent variable on one dependent variable. The independent variables include socio-economic, environmental and risk factors, namely birth weight, BCG immunization, history of exclusive breastfeeding, nutritional status, parents' income, home sanitation, exposure to cigarette smoke, family history of TB. Meanwhile, the dependent variable in this study is the incidence of $\mathrm{TB}$ in children.

\section{Research Ethics}

This study was conducted based on research ethics, namely informed consent, ano- nymity, confidentiality, and ethical eligibility. Ethics permission in this study was obtained from the Health Research Ethics Commission Dr. Moewardi Hospital, Surakarta, Indonesia, No. 1023 / VIII / HREC / 2019.

\section{RESULTS \\ 1. Sample Characteristics}

The categorical data sample description explains the continuous data of each study variable including birth weight, nutritional status, home sanitation, and family income shown by the table 1 .

Table 1. Description of characteristics of continuous data samples

\begin{tabular}{lccccc}
\hline \multicolumn{1}{c}{ Variable } & n & Mean & SD & Min. & Max. \\
\hline Birth weight (g) & 200 & 2865.75 & 414.455 & 2000 & 4200 \\
Nutritional Status (BMI) & 200 & 20.80 & 2.538 & 15.5 & 28.3 \\
House Sanitation & 200 & 21.25 & 1.818 & 17 & 25 \\
Family Income (Rp) & 200 & $2,763,500$ & $2,153,580$ & 900,000 & $15,000,000$ \\
\hline
\end{tabular}

Table 2. Description of the characteristics of the categorical data sample

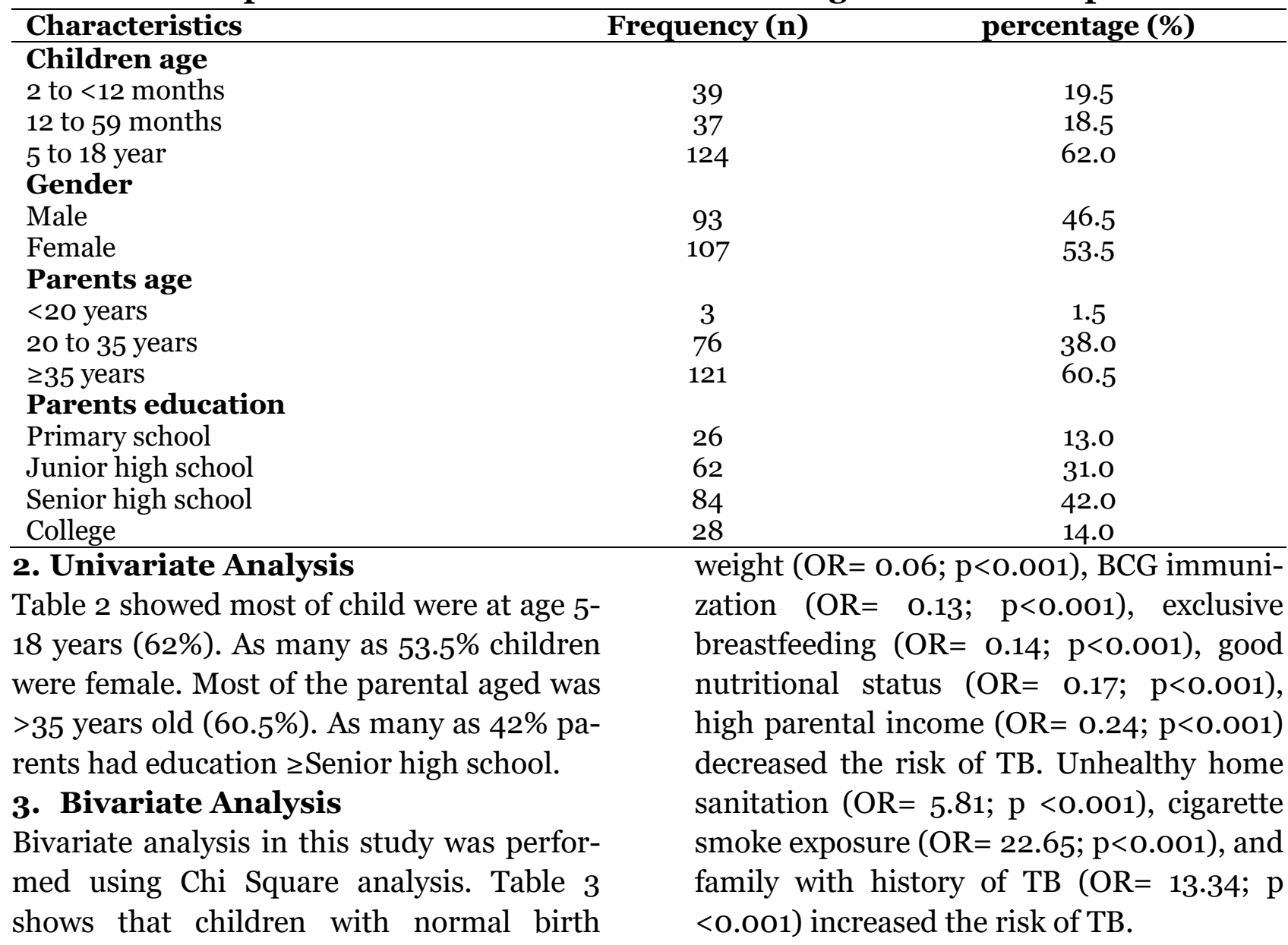


Table 3. Chi Square test factors that influence the incidence of TB in children

\begin{tabular}{|c|c|c|c|c|c|c|c|c|}
\hline \multirow{3}{*}{ Independent variables } & \multicolumn{4}{|c|}{ TB status } & \multirow{3}{*}{ OR } & \multicolumn{2}{|c|}{$95 \% \mathrm{CI}$} & \multirow{3}{*}{$\mathbf{p}$} \\
\hline & \multicolumn{2}{|c|}{ Non $T B$} & \multicolumn{2}{|c|}{ TB } & & \multirow{2}{*}{$\begin{array}{c}\text { Lower } \\
\text { limit }\end{array}$} & \multirow{2}{*}{$\begin{array}{l}\text { Upper } \\
\text { limit }\end{array}$} & \\
\hline & $\mathbf{n}$ & \% & $\mathbf{n}$ & $\%$ & & & & \\
\hline \multicolumn{9}{|l|}{ Birth weight } \\
\hline Low $(<2,500 \mathrm{~g})$ & 15 & 32.61 & 31 & 67.39 & 0.06 & 0.02 & 0.15 & $<0.001$ \\
\hline Normal $(\geq 2,500 \mathrm{~g})$ & 135 & 87.66 & 19 & 12.34 & & & & \\
\hline \multicolumn{9}{|l|}{ BCG Immunization } \\
\hline No & 8 & 34.78 & 15 & 14.9 & 0.13 & 0.04 & 0.36 & $<0.001$ \\
\hline Yes & 142 & 80.23 & 35 & 19.77 & & & & \\
\hline \multicolumn{9}{|l|}{ Exclusive Breastfeeding } \\
\hline No & 27 & $47 \cdot 37$ & 30 & 52.63 & 0.14 & 0.06 & 0.31 & $<0.001$ \\
\hline Yes & 123 & 86.01 & 20 & 13.99 & & & & \\
\hline \multicolumn{9}{|l|}{ Nutritional Status } \\
\hline Poor $(<18.5)$ & 19 & 45.24 & 23 & 54.76 & 0.17 & 0.07 & 0.37 & $<0.001$ \\
\hline Good $(\geq 18.5)$ & 131 & 82.91 & 27 & 17.09 & & & & \\
\hline \multicolumn{9}{|l|}{ Parents Income } \\
\hline Low (<Rp. $1,802,700)$ & 46 & 58.97 & 32 & 41,03 & 0.24 & 0.11 & 0.51 & $<0.001$ \\
\hline High ( $\geq$ Rp. $1,802,700)$ & 104 & 85.25 & 18 & 14.75 & & & & \\
\hline \multicolumn{9}{|l|}{ House sanitation } \\
\hline Healthy & 13 & 29.55 & 31 & 70.45 & 5.81 & 2.23 & 11.39 & $<0.001$ \\
\hline Unhealthy & 137 & 87.82 & 19 & 12.18 & & & & \\
\hline \multicolumn{9}{|l|}{ Smoke exposure } \\
\hline Yes & 32 & 42.67 & 43 & $57 \cdot 33$ & 22.65 & 8.84 & 64.16 & $<0.001$ \\
\hline No & 118 & 94.40 & 7 & 5.60 & & & & \\
\hline \multicolumn{9}{|l|}{ Family History of TB } \\
\hline Yes & 9 & 28.12 & 23 & 71.88 & 13.34 & 5.17 & 35.92 & $<0.001$ \\
\hline No & 141 & 83.93 & 27 & 16.07 & & & & \\
\hline
\end{tabular}

\section{Multivariate Analysis}

The multivariate analysis method used was a multilevel multiple logistic regression analysis which was carried out using the
Stata 13. The multivariate analysis explained the effect of more than one independent variable on one dependent variable.

Table 4. Multilevel multiple logistic regression analysis of socioeconomic, enviromental and risk factors that influence TB in children

\begin{tabular}{|c|c|c|c|c|}
\hline \multirow{2}{*}{ Independent Variables } & \multirow{2}{*}{$\mathbf{O R}$} & \multicolumn{2}{|c|}{$95 \%$ CI } & \multirow[b]{2}{*}{$\mathbf{p}$} \\
\hline & & Lower limit & Upper Limit & \\
\hline \multicolumn{5}{|l|}{ Fixed Effect } \\
\hline Birth weight ( $\geq 2,500$ gram $)$ & 0.12 & 0.02 & 0.60 & 0.009 \\
\hline BCG immunization (yes) & 0.17 & 0.04 & 0.64 & 0.009 \\
\hline Exclusive breastfeeding history (yes) & 0.08 & 0.01 & 0.57 & 0.011 \\
\hline Nutritional status (good) & 0.11 & 0.02 & 0.66 & 0.016 \\
\hline Parents income ( $\geq$ Rp. 1,802,700) & 0.07 & 0.01 & 0.37 & 0.002 \\
\hline House sanitation (unhealthy) & 6.70 & 1.14 & 39.27 & 0.035 \\
\hline Smoke exposre (yes) & 6.71 & 1.09 & 41.25 & 0.040 \\
\hline Family history of TB (yes) & 6.01 & 1.36 & 26.39 & 0.018 \\
\hline \multicolumn{5}{|l|}{ Random Effect } \\
\hline Var (Constata) & 1.36 & 0.09 & 19.58 & Village \\
\hline $\mathrm{N}$ observation & 200 & & & \\
\hline LR test vs. Logistic Regression, $\mathrm{p}=0.013$ & & & & \\
\hline Intraclass Correlation (ICC) $=29.24 \%$ & & & & \\
\hline
\end{tabular}


Journal of Epidemiology and Public Health (2019), 4(4): 361-372

https://doi.org/10.26911/jepublichealth.2019.04.04.11

Table 4 shows there are socioeconomic, environmental and risk factors such as birth weight, BCG immunization, history of exclusive breastfeeding, nutritional status, parental income, home sanitation, exposure to cigarette smoke and family history of TB. The risk of TB incidence in children decreases with normal birth weight $(\mathrm{OR}=0.12 ; \mathrm{p}=$ 0.009), $\mathrm{BCG}$ immunization $(\mathrm{OR}=0.17 ; \mathrm{p}=$ o.0og), exclusive breastfeeding ( $\mathrm{OR}=0.08$; $\mathrm{p}=0.011)$, good nutritional status $(\mathrm{OR}=$ $0.11 ; \mathrm{p}=0.016)$ and high parental income $(\mathrm{OR}=0.07 ; \mathrm{p}=0.002)$. The risk of pediatric TB incidence increased with unhealthy home sanitation $(\mathrm{OR}=6.70 ; \mathrm{p}=0.035)$, exposure to cigarette smoke $(\mathrm{OR}=6.71 ; \mathrm{p}=$ $0.040)$ and family history of TB (OR=6.01; $\mathrm{p}=0.018$ ). There was a contextual effect on the risk of the incidence of $\mathrm{TB}$ in children (ICC $=29.24 \%$ ).

\section{DISCUSSION \\ 1. The effect of birth weight on the risk of $T B$ incidence in children}

The results showed that children who had normal birth weight had a lower risk of developing $\mathrm{TB}$, which was 0.12 times compared to children who had low birth weight.

Children with low birth weight tend to easily experience decreased respiratory function and have an increased risk of chronic respiratory disease during childhood (Lee et al., 2003). The results of the study of Xin et al. (2019), also states that children with low birth weight will experience impaired immune function. The more severe growth retardation experienced by the fetus, the more severe the damage to lung structure and function, as well as immunocompetent disorders and such damage will persist throughout childhood. Low birth weight is related to immaturity in the respiratory organs, this will influence the initial adaptation process in response to various exposures (Florescu et al., 2015).

\section{The effects of BCG immunization on the risk of $T B$ in children}

The results showed that children who received BCG immunization had a lower risk of developing $\mathrm{TB}$, which was 0.17 times compared to children who did not get BCG immunization.

Children who do not get BCG vaccination according to their age based on recommendations from the Indonesian Ministry of Health have a higher risk of developing TB compared to children who get BCG vaccination (Hu et al., 2013). Jain et al. (2013) mention this shows that the prevalence of TB among school children can be reduced by strengthening the BCG vaccination under the national immunization program as a strategy for the prevention of active TB (Setiyaningsih et al., 2019).

\section{The effects of a history of exclusive breastfeeding on the risk of TB in- cidence in children}

The results showed that children who received exclusive breastfeeding had a lower risk of developing TB, which was 0.08 times compared to children who did not get exclusive breastfeeding.

Infants who are exclusively breastfed have a lower risk of developing TB compared to children who are not exclusively breastfed (Hanieh et al., 2015). The content in breast milk that babies drink during exclusive breastfeeding is sufficient for the baby's needs and is in accordance with the baby's health (Fitriani et al., 2019). Breast milk contains immunity to infections including proteins, lysozyme, lactoferrin, immunoglobulins and antibodies against bacteria, viruses, fungi and other pathogens (Aziz, 2018).

Breast milk also increases antibody responses to pathogens in the respiratory tract and increases the immune system. Therefore exclusive breastfeeding reduces child mortality due to various diseases such 
as $\mathrm{TB}$ and accelerates recovery when sick (Grant et al., 2011)

\section{The effect of nutritional status on the risk of TB incidence in children}

The results showed that children with good nutritional status had a lower risk of developing TB, which was o.11 times compared to children with low nutritional status

Children with malnutrition have a risk of TB of 3.96 times compared with children who have good nutrition (Tekle et al., 2015). Other studies that are in line are research conducted by Grant et al. (2011), it was found that nutritional status has a direct influence on the incidence of TB. Children with poor nutritional status increase the risk of TB.

Malnutrition will cause a decrease in immune capacity to respond to TB infection including impaired granulocyte function, decreased complement function and cause micronutrient deficiencies, disruption of bactericidal phagocytic activity (Ibrahim et al., 2017). Malnutrition in childhood usually involves inadequate intake of protein and calories, with increased micronutrient deficiency (Xin et al., 2019). Protein and micronutrient deficiencies have an impact on hematopoietic and lymphoid organs. Changes related to malnutrition in intestinal microbiota contribute to growth disorders and irregular inflammation and immune function (Jain et al., 2013).

\section{The effect of parental income on the risk of $\mathrm{TB}$ incidence in children} The results showed that children with highincome parents have a lower risk of developing TB, which is 0.07 times compared to children with low-income parents.

Children from families with low economic status are more at risk of communicable diseases (Simkovich et al., 2019). Socio-economics is a determining factor for meeting the needs of life, including the quality of sanitation in homes that meet heal- thy requirements (Fitriani et al., 2019). Nutritious food needs and other needs that support the health conditions of family members (Alyahya et al., 2017). Low-income families have limitations in meeting the needs of life that support the whole as well as limited access in preventive and curative efforts (Bai et al., 2018). Low-income families, then the results of their work only to meet their basic daily needs are not optimal (Karim et al., 2012).

\section{The effect of home sanitation on the risk of $\mathrm{TB}$ incidence in children} The results showed that children who live at home with sanitation quality that do not meet the healthy requirements have a higher risk of developing $\mathrm{TB}$, which is 6.70 times compared to children who live at home with sanitation quality that meets healthy conditions.

The physical condition of the home environment that does not meet health requirements can support the transmission of diseases and health problems such as TB (Xin et al., 2019). The condition of the physical environment of the house (temperature, natural lighting intensity, type of wall, house floor, ventilation, humidity, occupancy density) is significantly related to the incidence of TB in children (Karim et al., 2012). The government has established regulations regarding housing health requirements, namely Decree of the Minister of Health of the Republic of Indonesia Number 829/MENKES/SK/VII/1999 concerning Housing Health Requirements.

The proportion of houses in Indonesia that met healthy house requirements in 2013 was still low at $24.9 \%$. The findings in this study, about $22 \%$ of housing units are houses that do not meet healthy requirements (Surakarta Health Office, 2019). The condition of the physical environment of homes that do not meet health requirements can increase the risk of diseases such 
Journal of Epidemiology and Public Health (2019), 4(4): 361-372

https://doi.org/10.26911/jepublichealth.2019.04.04.11

as TB (Ramadhiana et al., 2016). According to Shimeles et al. (2019), home physical environment factors are factors that influence the emergence of lung disease in addition to population factors (gender, age and socioeconomic).

Conditions that are not good air humidity is a good medium for the growth of bacteria and viruses that cause diseases including TB (Duarte et al., 2018). Transmission of respiratory diseases is more common in homes that do not meet health requirements because the number of germs is greater than the air that is exchanged (Alyahya et al., 2017).

\section{The effect of exposure to cigarette smoke on the risk of TB in children}

The results showed that children who live with family members who smoke have a higher risk for experiencing $\mathrm{TB}$, which is 6.71 times compared to children who live with family members who do not smoke.

Air pollution from cigarette smoke increases the risk of TB occurrence in children (Adesanya et al., 2016). TB is a serious disease problem caused by various factors, one of which is cigarette smoke (Adetifa et al., 2017). Polycyclic Aromatic Hydrocarbons (PAHS) are harmful to human health from the combustion of tobacco products that are usually in the form of cigarette smoke (Environmental Tobaco Smoke / ETS) which is a type of toxic gas (Simkovich et al., 2019).

Cigarette smoke around smokers contains the same toxic and carcinogenic ingredients as smoked by smokers so that the effect on passive smokers is almost the same as active smokers (Koretskaya et al., 2017). Cigarette smoke in addition to carcinogenic effects, can also cause respiratory infections by sulfur dioxide, ammonia and formaldehyde (Patra et al., 2015).

\section{The effects of family history of TB. on the risk of TB in children}

The results showed that children who lived with family members who had a history of TB had a higher risk of experiencing TB, which was 6.01 times compared to children who lived with family members who did not have a history of TB.

Every TB case in a child is caused by contact with an infected person. Another factor is the number of people living in the same house, the length of time living together, and sharing a room with TB sufferers (Shimeles et al., 2019). Contact with a smear adult TB (+) is a risk factor for TB infection (Adetifa et al., 2017). This difference can be explained by the length of exposure and virulence of $M$. tbc from individuals with TB (Jain et al., 2013). Intimate contact with $\mathrm{TB}$ cases is significantly associated with smear-positive TB (Hu et al., 2013). The prevalence among school children can be reduced by increasing the investigation of active contact of TB patients (Patra et al., 2015).

\section{Contextual effect of village on the risk of $\mathrm{TB}$ in children}

The results of multilevel analysis show that the ICC value $=29.24 \%$, the indicator shows that the condition of each kelurahan area has a contextual influence on the variation in the occurrence of TB in children.

Epidemiological triangle theory explains that the emergence of disease is caused by the influence of host factors (host), causes (agents) and the environment (environment). The environment outside the individual (host) plays an important role in increasing TB in children (Murti, 2016).

Living in poor communities can cause psychosocial stress, which can lead to negative behaviors that can have a negative impact on the health of those around them, such as smoking (Ade-sanya and Chiao, 2016). The degree of health and poverty of 
people in an area affect each other (Ramadhiana et al., 2016). An increase in income does not automatically guarantee poverty reduction unless the health status of the poor is also increased. Health service financing must also get attention so that there is an increase in health status, this will have an impact on increasing the income of its population (Chisti et al., 2015).

The poverty condition also affects the public health behavior of each village/ kelurahan which is also different (Bai et al., 2018). Villages / villages where the majority of people have access to health information tend to have a high awareness of health and will usually influence surrounding residents to jointly care about health (Caesar et al., 2017). Vice versa, residents who live in poor communities mostly have limited access to health information and tend to have a lack of awareness of health, the surrounding environment can be affected and do not care about negative behavior (Cross et al., 2014).

The condition of settlements in each village/kelurahan is different, there are several villages that have a large distance from one house to another, so that the air flow to each house is better than villages/ kelurahan which have narrow and densely populated houses, where sometimes the lighting for passing through the window is often closed by other houses which causes suboptimal humidity and temperature in the house (Murakami et al., 2019).

\section{AUTHOR CONTRIBUTION}

Dyah Ayu Saputri collected data, did data analysis, and wrote the manuscript. Bhisma Murti did data analysis and interpreted the results of data analysis. Yulia Lanti Retno Dewi formulated the research framework and suggested the materials of nutritional status as determinants of TB incidence in children.

\section{FUNDING AND SPONSORSHIP}

This study is self-funded.

CONFLICT OF INTEREST

There is no conflict of interest in this study.

\section{ACKNOWLEDGMENT}

$\overline{\text { Acknowledgments were conveyed by author }}$ to the Head of the community health centers and the Head of village in Surakarta, Central Java, in which allowed this study to be carried out.

\section{REFERENCE}

$\overline{\text { Adesanya OA, Chiao C (2016). A multilevel }}$ analysis of lifestyle variations in symptoms of acute respiratory infection among young children under five in Nigeria. BMC Public Health. 16(1): 880. https://doi.org/10.1186/s12889016-3565-o

Adetifa IMO, Kendall L, Donkor S, Lugos MD, Hammond AS, Owiafe PK, Hill PC (2017). Mycobacterium tuberculosis infection in close childhood contacts of adults with pulmonary tuberculosis is increased by secondhand exposure to tobacco. Am J Trop Med Hyg. 97(2): 429-432. https://doi.org/10.4269/ajtmh.10611

Alyahya IA, Almohsen HA, Alsaleem IA, Mishari MAA, Turki, Yousef A, Abdulmajeed, Abdulrahman, Aljasser MAA (2017). Assessment of knowledge, attitude, and practice about first aid among male school teachers and administrators in Riyadh, Saudi Arabia. Journal of Family Medicine and Primary Care. 6(2): 169-170. https://doi.org/10.4103/jfmpc.jfmpc

Ari NP, Yulia LRN, Setyo SR (2019). Factors associated with success rate for tuberculosis treatment in hospital: a 
Journal of Epidemiology and Public Health (2019), 4(4): 361-372

https://doi.org/10.26911/jepublichealth.2019.04.04.11

directly observed treatment short tuberculosis prevention strategy in central java. J Epidemiol Public Health. 4(4): 283-295. https://doi.org/10.26911/jepublichealth.2019.04.04.03.

Aziz KH (2018). Hubungan pemberian ASI eksklusif dengan kejadian tuberkulosis paru pada anak. Jurnal Info Kesehatan. 16(2): 0216-504. https://doi.org/10.31965/infokes

Bai X, Aerts SL, Verma D, Ordway DJ, Chan ED (2018). Epidemiologic evidence of and potential mechanisms by which second-hand smoke causes predisposition to latent and active tuberculosis. Immune Network. 18(3): 119. https://doi.org/10.4110/in.2018.18.e22.

Caesar V, Fidelia M, Rachel JEJ (2017). The impact of eimeria tenella co-infection on campylobacter jejuni colonisation of the chicken. Infection and immunity. LSHTM Research Online. 61: 6167. https://doi.org/10.17037/PUBS.03482693.

Chisti MJ, Ahmed T, Shahid ASMSB, Shahunja KM, Bardhan PK, Faruque ASG, Salam MA (2015). Sociodemographic, epidemiological, and clinical risk factors for childhood pulmonary tuberculosis in severely malnourished children presenting with pneumonia: observation in an urban hospital in Bangladesh. Glob Pediatr Health. 2: 2333794X15594183. doi: 10.1177/233$3794 \mathrm{X} 15594183$.

Cross GB, Coles K, Nikpour M, Moore OA, Denholm J, McBryde ES (2014). TB incidence and characteristics in the remote gulf province of Papua New Guinea: a prospective study. BMC Infect Dis. 14: 93. doi: 10.1186/1471-2334-14-93.

Duarte R, Lonnroth K, Carvalho C, Lima F, Carvalho ACC, Munoz TM, Centis R
(2018). Tuberculosis, social determinants and co-morbidities (including HIV). Pulmonology. 24(2): 115-119. https://doi.org/10.1016/j.rppnen.2017.11.003

Fitriani TG, Rahardjo SS, Prasetya H (2019). Biological and social economic determinants of adherence and cure of tuberculosis treatment: path analysis evidence from Yogyakarta. J Epidemiol Public Health. 4(4): 270-282. https://doi.org/10.26911/jepublichealth.2019.04.04.02

Grant CC, Wall CR, Gibbons MJ, Morton SM, Santosham M, Blach RE (2011). Child nutrition and lower respiratory tract disease burden in New Zealand: a global context for a national perspective. J Paediatr Child Health. 47 (8): 497-504. Retrieved from https://www.ncbi.nlm.nih.gov/pubmed/21040074

Hanieh S, Ha TT, Simpson JA, Thuy TT, Khuong NC, Thoang DD, Biggs BA (2015). Exclusive breast feeding in early infancy reduces the risk of inpatient admission for diarrhea and suspected pneumonia in rural Vietnam: A prospective cohort study. BMC $\mathrm{Pu}-$ blic Health. 15(1): 1-10. doi: 10.1186/s12889-015-2431-9

Hu Y, Zhao Q, Wu L, Wang W, Yuan Z, Xu $B$ (2013). Prevalence of latent tuberculosis infection and its risk factors in schoolchildren and adolescents in Shanghai, China. Eur J Public Health. 23(6): 1064-9. doi: 10.1093/eurpub/ckt105.

Ibrahim MK, Zambruni M, Melby CL, Melby PC (2017). Impact of childhood malnutrition on host defense and infection. Clin Microbiol Rev. 30(4): 919-971. doi: 10.1128/CMR.00119-16.

Jain SK, Ordonez A, Kinikar A, Gupte N, Thakar M, Mave V (2013). Pediatric 
tuberculosis in young children in India: a prospective study. Biomed Res Int. 20(13): 783698. doi: 10.1155/2$013 / 783698$.

Karim M, Rahman MA, Mamun SA, Alam MA, Akhter S (2012). Risk factors of childhood tuberculosis: a case control study from rural Bangladesh. WHO South East Asia. J Public Health. 1(1): 76-84. doi: 10.4103/22243151.206917.

Koretskaya NM, Narkevich AN, Narkevich AA, Grin EN (2017). Tuberculosis and tobacco smoking: a risk of development and specific features in smoking patients. Pulmonologiya. 27(1): 5155. https://doi.org/10.18093/o869-0189-2017-27-1-51-55

Lee WB, Brown HL, Steele G (2003). Assessing parental birth weight as a risk factor for low-birth-weight delivery. obstetrics gynecology. 101: 40S. https://doi.org/10.1097/00006250200304001-00092

Ministry of Health (2019). Pusat data dan Informasi kementerian kesehatan 2019. Retrieved from https://www.depkes.go.id/resources/download/pusdatin/profil-kesehatanindonesia/Data-dan Informasi_Profil-Kesehatan Indonesia2019.pdf

Ministry of Health (2015). Profil Kesehatan RI 2015. Profil Kesehatan Indonesia Tahun 2015. https://doi.org/10.1111/evo.12990

Murakami R, Matsuo N, Ueda K, Nakazawa $M$ (2019). Epidemiological and spatial factors for tuberculosis: a matched case-control study in Nagata, Japan. Int Jurnal Tuberc Lung Dis. 23(2): 181-186. doi: 10.5588/ijtld.18.0369

Patra J, Bhatia M, Suraweera W, Morris SK, Patra C, Gupta PC, Jha P (2015) Exposure to second-hand smoke and the risk of tuberculosis in children and adults: a systematic review and metaanalysis of 18 observational studies. PLoS Med. 12(6): e1001835. doi: 10.1371/journal.pmed.1001835

Ramadhiana Y, Probandari AN, Setianingsih W (2016). Factors associated with success rate for tuberculosis treatment in hospital : a directly observed treatment short tuberculosis prevention strategy in Central Java. J Epidemiol Public Health. 4(4): 283-295 https://doi.org/10.26911/jepublicheal th.2019.04.04.03

Setiyaningsih R, Lanti Y, Dewi R, Adriani $R B$ (2019). Contextual effect of school on the risk obesity among high school students in Surakarta, Central Java : A Multilevel Analysis Evidence. J Epidemiol Public Health. 4(4): 328-337. https://doi.org/10.26911/jepublichealth.2019.04.04.08

Shimeles E, Enquselassie F, Aseffa A, Tilahun M, Mekonen A, Wondimagegn G, et al (2019) Risk factors for tuberculosis: a case control study in addis ababa, Ethiopia. PLoS ONE. 14(4): eo214235. https://doi.org/10.1371/journal.pone.0214235

Simkovich SM, Goodman D, Roa C, Crocker ME, Gianella GE, Kirenga BJ (2019). The health and social implications of household air pollution and respiratory diseases. NPJ Prim Care Respir Med. 29(1): 12. doi: 10.1038/s41533019-0126-X

Tekle AG, Worku A, Birhane Y (2015). Factors associated with acute respiratory infection in children under the age of 5 years: evidence from the 2011 Ethiopia Demographic and Health Survey. $P$ Health Medicine and Therapeutics. 129. https://doi.org/10.2147/phmt.s87065

WHO (2016). Integrated Management of Childhood Illness (IMCI) (Revised). 
Journal of Epidemiology and Public Health (2019), 4(4): 361-372

https://doi.org/10.26911/jepublichealth.2019.04.04.11

Geneva: WHO/ UNICEF. Retrieved from https://www.who.int/maternal_child_adolescent/topics/child/imci/ en/

Xin H, Zhang H, Liu J, Pan S, Li X, Cao X, et al. (2019). Mycobacterium tubercu- losis infection among the elderly in 20 486 rural residents aged 50-70 years in Zhongmu County, China. Clin Microbiol Infect. 25(9): 1120-1126. doi: 10.1016/j.cmi.2019.01.021 